\title{
Children and Videogames: Leisure Activities, Aggression, Social Integration, and School Performance ${ }^{1}$
}

\author{
EMIL G. M. VAN SCHIE ${ }^{2}$ AND OENE WIEGMAN \\ University of Twente, Enschede, The Netherlands
}

\begin{abstract}
A survey was conducted among 346 children from the 7 th and 8 th grade of 7 elementary schools to examine possible positive and negative effects of playing videogames. Analyses revealed that playing videogames did not appear to take place at the expense of children's other leisure activities, social integration, and school performance. A gender difference arose: Boys spent more time playing videogames than did girls. There was no significant relationship between the amount of time children spent on videogames and aggressive behavior. A negative relationship between time spent playing videogames and prosocial behavior was found; however, this relationship did not appear in separate analyses for boys and girls. Furthermore, a positive relationship was found between time spent on videogames and a child's intelligence.
\end{abstract}

The increase in the purchase of videogames (Central Bureau of Statistics, 1993, 1994) appears to be coupled with an increasing debate about positive and negative effects of these games. Some authors point out the usefulness of videogames in therapies, education, and social interaction (Malone, 1981; Stowbridge \& Kugel, 1983; Winkel, Novak, \& Hopson, 1987). Others find that because of the often aggressive content of videogames, aggressive behavior and thoughts will gain the upper hand, so videogame players will give less attention to the well-being of others (Anderson \& Ford, 1986). Furthermore, videogames could be addictive, and social skills could suffer under prolonged playing (Anderson \& Ford, 1986; Griffiths, 1991, 1993; Griffiths \& Hunt, 1993; Shotton, 1989; Soper \& Miller, 1983).

Critics of videogames particularly emphasize the aggressive element in videogames and the aggressive behavior they bring about. Meta-analytic studies into

\footnotetext{
'We thank the following for their valuable contributions to this research: Arnoud Breedijk, Marco Wiedijk, Margot Kuttschreuter, and Henk Boer; members of our Department of Psychology who helped collecting the data; the Department of Education of the municipality of Enschede, The Netherlands; and the children and their teachers.

${ }^{2}$ Correspondence concerning this article should be addressed to Emil van Schie, Department of Psychology, University of Twente, P.O. Box 217, NL-7500 AE Enschede, The Netherlands.
}

\section{5}

Journal of Applied Social Psychology, 1997, 27, 13, pp. 1175-1194.

Copyright (c) 1997 by V. H. Winston \& Son, Inc. All rights reserved. 
the relationship between watching television and aggression show that watching aggressive television programs induces aggressive behavior (Hearold, 1986; Paik \& Comstock, 1994; Wood, Wong, \& Chachere, 1991). However, the possible influence of videogames might be less than that of television programs, as the violence portrayed in videogames is often more abstract (characters often look like figures from a comic book). On the other hand, the influence of videogames on a child's behavior and thoughts could be more intense because many videogames demand an active effort of the player who is often rewarded for his or her aggressive acts.

With respect to the relationship between playing videogames and aggressive behavior, we distinguish between two theoretical approaches. The first and most common approach is based on the stimulation hypothesis. Based on Bandura's social learning theory, this approach highlights the process of modeling in which an individual imitates, under certain circumstances, the behavior of an observed model (Bandura, 1977, 1986; see also Kuttschreuter, Wiegman, \& Baarda, 1986; Wiegman, 1975; Wiegman, Kuttschreuter, \& Baarda, 1986; Wiegman, Seydel, \& Baarda, 1983). Assumptions are made that children who play aggressive videogames will imitate certain aggressive behaviors.

In experimental studies, Silvern and Williamson (1987) and Schutte, Malouff, Post-Gorden, and Rodasta (1988) established that children imitated the aggressive behavior of the character in the videogame they played before; Cooper and Mackie (1986) established this effect only for girls. A limitation of these studies is that researchers only used one aggressive videogame and subsequently only looked at short-term effects of this game.

Studies on relationships between aggressive videogames and aggressive behavior have also been done with teenagers and adults. Winkel et al. (1987) found that teenagers who had been playing a violent videogame were not displaying significantly more aggressive behavior in a teacher-learner paradigm. After playing a videogame, these teenagers had to punish a learner by deducting money, a measure of aggression, whenever the learner made a mistake. However, in a study by Chambers and Ascione (1987), children donated significantly less money to a charitable cause after playing an aggressive videogame. Anderson and Ford (1986) found that students who played a very aggressive videogame showed more hostility and anxiety. A study by Fling et al. (1992) showed that not only playing aggressive videogames was related to an increase in aggressive behavior, but that there was also a relationship with time spent playing videogames. They found that the more time young people play videogames, the more aggressive they are considered by their teachers and the more these young people think of themselves as behaving aggressively.

The second approach is based on the catharsis hypothesis (Feshbach \& Singer, 1971) by proposing that videogames have a relaxing effect: Playing a 
videogame can be a way of channeling latent aggression, by which aggression decreases. Graybill, Kirsch, and Esselman (1985) observed that children had less ego-defensive and more assertive fantasies after playing a violent videogame.

The assumption that videogames can play a role in the discharge of aggression was stressed by Kestenbaum and Weinstein (1985) who found that videogames seem to have a calming effect on boys who often play these games. In a case study, Gardner (1991) described that the use in therapeutic sessions of the game Mario Bros. contributed to a decrease in the aggressive behavior of a young boy. However, Gardner's study was concerned with the investigation of the effects of just one videogame on just one child. In Table 1, the results of the studies mentioned above are briefly summarized.

Prosocial behavior has also been involved in research into the effects of videogames. Wiegman, Kuttschreuter, and Baarda (1992) defined prosocial behavior as an act in which a person supports or helps another person or persons such that the actor knows beforehand that his or her behavior will result in positive consequences for the other person(s). One study in which prosocial behavior was measured is the one reported earlier by Chambers and Ascione (1987). They had children play an aggressive or prosocial videogame on their own or with a fellow player and concluded that the prosocial videogame had no significant effect upon donating money.

Videogames can also influence the child's social integration. In a number of studies, it has been established that children behave more socially after playing videogames. Shimai, Masuda, and Kishimoto (1990) asked parents about their children's experiences with the so-called Family Computer (Famicom), a game computer connected to a television, with which more people can simultaneously participate in a game. The children who played Famicom games turned out to be more socially skilled, compared to children who did not play these games.

According to opponents of videogames, it is possible that a child becomes socially isolated by spending much time playing videogames. Selnow (1984) concluded that videogame players perceive the game as a surrogate companion, as their electronic friend. Heavy users of videogames were more likely than less frequent videogame players to agree that playing videogames is more fun and more desirable than being with other children. Lin and Lepper (1987), on the other hand, reported no relationship between the use of videogames and social alienation or isolation. Mitchell (1985) even observed an increase in social interaction within the family after the acquisition of a videogame. Colwell, Grady, and Rhaiti (1995) reported that children, in particular boys, who often played videogames behaved more sociably: They were more likely to see friends outside school. A list of studies into the effects of videogames on prosocial behavior and social skills is presented in Table 2 . 


\section{Table 1}

Overview of Studies of the Relationship Between Playing Videogames and Aggression

\begin{tabular}{|c|c|c|c|c|}
\hline Authors & Type of study & Age & $N$ & Results \\
\hline $\begin{array}{l}\text { Schutte, Malouff, } \\
\text { Post-Gorden, \& } \\
\text { Rodasta (1988) }\end{array}$ & Experiment & $5-7$ & 31 & $\begin{array}{l}\text { In a free play situation children } \\
\text { imitated the aggressive be- } \\
\text { havior of the leading character } \\
\text { in an aggressive videogame }\end{array}$ \\
\hline $\begin{array}{l}\text { Silvern \& } \\
\text { Williamson (1987) }\end{array}$ & Experiment & $4-6$ & 28 & $\begin{array}{l}\text { After playing an aggressive } \\
\text { videogame for a while, children } \\
\text { behaved more aggressively in } \\
\text { a free play situation }\end{array}$ \\
\hline $\begin{array}{l}\text { Cooper \& Mackie } \\
(1986)\end{array}$ & Experiment & $\begin{array}{l}\text { 4th-5th } \\
\text { grade }\end{array}$ & 84 & $\begin{array}{l}\text { Girls behaved more aggres- } \\
\text { sively in a free play situation } \\
\text { after playing an aggressive } \\
\text { videogame }\end{array}$ \\
\hline $\begin{array}{l}\text { Anderson \& Ford } \\
\text { (1986) }\end{array}$ & Experiment & $\begin{array}{l}\text { University } \\
\text { under- } \\
\text { graduates }\end{array}$ & 60 & $\begin{array}{l}\text { A high-aggressive game led to } \\
\text { higher hostility among students } \\
\text { than a mild-aggressive game }\end{array}$ \\
\hline $\begin{array}{l}\text { Winkel, Novak, } \\
\text { \& Hopson (1987) }\end{array}$ & Experiment & 8 th grade & 56 & $\begin{array}{l}\text { Teenagers did not show more } \\
\text { aggressive behavior in a } \\
\text { teacher/learner role play after } \\
\text { playing an aggressive video- } \\
\text { game; they adjudged no more } \\
\text { punishment to a failing learner }\end{array}$ \\
\hline $\begin{array}{l}\text { Chambers \& } \\
\text { Ascione (1987) }\end{array}$ & Experiment & $\begin{array}{l}8-12 \\
12-15\end{array}$ & 160 & $\begin{array}{l}\text { Aggressive game conditions } \\
\text { suppress the donating of } \\
\text { money; after playing an agres- } \\
\text { sive videogame, children gave } \\
\text { less money to a good cause }\end{array}$ \\
\hline $\begin{array}{l}\text { Fling, Smith, } \\
\text { Rodriguez, } \\
\text { Thornton, Atkins, } \\
\text { \& Nixon (1992) }\end{array}$ & Survey & $\begin{array}{l}\text { 6th-12th } \\
\text { grade }\end{array}$ & 153 & $\begin{array}{l}\text { The more often youngsters } \\
\text { play videogames, the more } \\
\text { aggressive these youngster } \\
\text { think they are, and the more } \\
\text { aggressive their teachers } \\
\text { think these youngsters are }\end{array}$ \\
\hline
\end{tabular}

(table continues) 
Table 1 (Continued)

\begin{tabular}{|c|c|c|c|c|}
\hline Authors & Type of study & Age & $N$ & Results \\
\hline $\begin{array}{l}\text { Graybill, Kirsch, } \\
\text { \& Esselman } \\
(1985)\end{array}$ & Experiment & $\begin{array}{l}\text { 2nd, } 3 \text { rd, } \\
\text { 6th grade } \\
\text { element- } \\
\text { ary school }\end{array}$ & 116 & $\begin{array}{l}\text { Children had more assertive and } \\
\text { less defensive fantasies after } \\
\text { playing an aggressive video- } \\
\text { game }\end{array}$ \\
\hline $\begin{array}{l}\text { Kestenbaum \& } \\
\text { Weinstein (1985) }\end{array}$ & Survey & $11-14$ & 208 & $\begin{array}{l}\text { Playing videogames can have } \\
\text { discharging effects; for boys, } \\
\text { these games had a calming } \\
\text { effect }\end{array}$ \\
\hline Gardner (1991) & Case study & $5,7,10$ & 3 & $\begin{array}{l}\text { In a therapeutic environment, } \\
\text { playing a certain videogame } \\
\text { can contribute to releasing and } \\
\text { controlling aggressive behavior }\end{array}$ \\
\hline
\end{tabular}

Lin and Lepper (1987) examined the relationship between playing videogames and school performance and found that time spent playing arcade videogames was negatively correlated with mathematics and general academic achievement. However, no significant relationship was found regarding home videogames. Lin and Lepper explained this difference by stating that a child who plays in an arcade often skips school, so school performance will suffer. Playing home videogames is not attended with truancy. Funk (1992) also noticed that hanging about in arcades could have negative effects on time spent doing homework or reading books.

Although worldwide a reasonable number of studies have been conducted into the effects of videogames, little is known about the present-day situation concerning videogames in the Netherlands. The purpose of this study is to investigate the possible relationships between playing videogames and leisure activities, aggressive behavior, prosocial behavior, social integration, and school performance of Dutch children.

We were interested in the amount of time children spent playing videogames. Shimai et al. (1990), Lin and Lepper (1987), and Joossens (1994) studied this aspect in Japan, the United States, and Flanders, respectively. Especially of interest to us is a comparison of our Dutch subjects with the subjects of the above-mentioned studies.

We investigated the relationship between the amount of time children spent playing videogames and other leisure activities. We assumed that playing 
Table 2

Overview of Studies of the Relationship Between Playing Videogames and Prosocial Behavior and Social Skills

\begin{tabular}{|c|c|c|c|c|}
\hline Authors & Type of study & Age & $N$ & Results \\
\hline $\begin{array}{l}\text { Chambers \& } \\
\text { Ascione (1987) }\end{array}$ & Experiment & $8-12,12-15$ & 160 & $\begin{array}{l}\text { After playing a prosocial } \\
\text { videogame, there was no } \\
\text { influence of this game on } \\
\text { donating money to a good } \\
\text { cause }\end{array}$ \\
\hline $\begin{array}{l}\text { Shimai, Masuda, } \\
\text { \& Kishimoto } \\
(1990)\end{array}$ & Survey & $3-5$ & 408 & $\begin{array}{l}\text { Children who played with } \\
\text { the Family Computer are } \\
\text { more socially skilled than } \\
\text { children who did not play } \\
\text { with this apparatus }\end{array}$ \\
\hline Selnow (1984) & Survey & $10-14$ & 244 & $\begin{array}{l}\text { Children who spent a lot of } \\
\text { time playing videogames } \\
\text { think more that playing these } \\
\text { games is more fun and } \\
\text { exciting than associating } \\
\text { with other children; video- } \\
\text { games are a substitute for } \\
\text { friendship and social } \\
\text { interaction }\end{array}$ \\
\hline $\begin{array}{l}\text { Lin \& Lepper } \\
(1987)\end{array}$ & Survey & $\begin{array}{l}\text { 4th-6th } \\
\text { grade }\end{array}$ & 210 & $\begin{array}{l}\text { Playing videogames is not at } \\
\text { the cost of social activities; } \\
\text { there is no indication tha } \\
\text { the use of videogames goe } \\
\text { with social alienation or } \\
\text { isolation }\end{array}$ \\
\hline Mitchell (1985) & Survey & $5-17$ & 44 & $\begin{array}{l}\text { Within the family there is an } \\
\text { increase in positive social } \\
\text { interaction after purchasin } \\
\text { a videogame }\end{array}$ \\
\hline $\begin{array}{l}\text { Colwell, Grady, } \\
\text { \& Rhaiti (1995) }\end{array}$ & Survey & $11-17$ & 120 & $\begin{array}{l}\text { Boys who play videogames } \\
\text { often are more likely to see } \\
\text { friends outside school }\end{array}$ \\
\hline
\end{tabular}


videogames would be at the cost of other leisure activities, as reported by Lin and Lepper (1987) and Funk (1992).

At the same time we investigated the relationship between the amount of time children spent playing videogames and aggressive behavior. We predicted that, since a large portion of the videogames have an aggressive content (Bowman \& Rotter, 1983; Wiegman \& Van Schie, 1996), the amount of exposure to videogames will correlate positively with aggressive behavior. This prediction is partly based on the results of Fling et al. (1992).

Further, we examined the relationship between amount of time spent playing videogames and children's prosocial behavior. We expected that children who spend a great deal of time on videogames will display less prosocial behavior. This expectation is based on a study by Joossens (1994), which showed that most children prefer to play videogames alone, so playing videogames might often be an individual activity.

We also examined the relationship between time spent playing videogames and a child's social integration. Are children who spend a great deal of time on videogames more lonely, more socially isolated, and less popular just because they often play videogames on their own? Selnow (1984) suggested that children might see the videogame as their electronic friend. Because of this, we expect that children who spend much time playing videogames will be less socially integrated.

Finally, we explored the relationship between time spent playing videogames, school performance, and intelligence. To date, no earlier studies have involved the relationship between amount of time playing videogames and a player's intelligence. While heavy players might attend less to their homework, we expect that spending a lot of time on videogames will be at the expense of school performance. As playing videogames is coupled with a high level of concentration and cognitive skills, there might be a positive relationship between playing videogames and a child's intelligence. In addition, there is, naturally, a positive relationship between school performance and intelligence. In order to establish the relationship between playing videogames and school performance in a pure manner, we corrected for the IQ factor. IQ could be conceived as a third variable, partly explaining the relationship between playing videogames and school performance.

Method

\section{Subjects}

The sample consisted of 175 girls and 171 boys from the 7 th and 8 th grade from seven elementary schools in the municipality of Enschede, The Netherlands. This sample was considered representative because the schools are situated in various socioeconomic parts of this municipality (inner town, older quarters of this town, a village center and new building areas). The average age 
of the participating children was 11.5 years; the youngest child was 10 years old, and the oldest child was 14. Our choice for this age group was based on earlier research by Kruse (1992), which showed that children of this age spend a great deal of time on videogames.

\section{Procedure}

In June 1994, measures were done on the seven participating schools at three points in time. During one week (from Tuesday until Monday of the next week), children completed a diary in which they had to record their out-ofschool activities. This took approximately $15 \mathrm{~min}$ each day. One week later, during lessons, the children also completed a questionnaire pertaining to the variables involved in this study. This questionnaire took the children between $30 \mathrm{~min}$ and $1 \mathrm{hr}$. One week after completing the questionnaire, the children took an intelligence test presented in written form. This test was done in class in $1 \mathrm{hr}$. The data collected by diary, questionnaire, and intelligence test were not anonymous. However, we promised the children that their answers on all questions would be used without mentioning their names. In addition to these measurements, the teachers rated the children's school performance.

\section{Measures}

Leisure activities. During 1 week, the children registered in a diary how much time they spent on certain out-of-school activities on the day before. These activities were: playing videogames, watching television, listening to music, playing musical instruments, reading books, reading newspapers, reading comics, playing organized sports, playing nonorganized sports, playing outdoors, playing round games, playing indoors, and doing homework. We adopted seven of the mentioned activities from an earlier study by Kruse (1992). The five possible responses were not, from $1 \mathrm{~min}$ up to and including half an hour, from $30 \mathrm{~min}$ up to and including $1 \mathrm{hr}$, from $1 \mathrm{hr}$ up to and including $2 \mathrm{hr}$, and more than $2 \mathrm{hr}$ (values 1 to 5, respectively). Scores were calculated for each activity by adding the scores for the whole week and dividing by 7 .

Aggressive behavior. ${ }^{3}$ To measure aggression, the peer-nomination technique was used. This instrument for measuring aggressive behavior has been used by Wiegman et al. (1986). The children are to indicate which children in their class exhibit certain aggressive behaviors, such as sticking out their

\footnotetext{
${ }^{3}$ The peer-rate data for aggressive behavior, prosocial behavior, popularity, social status, and social isolation have been adapted for statistical use with the help of the SOCSTAT program (Thissen-Pennings \& Ten Brink, 1994).
} 
tongues, telling lies, and fighting ( 10 items). The aggression score for a child is the total number of times he or she is mentioned by classmates, divided by the total number of classmates. The internal consistency for this aggression measure was Cronbach's $\alpha=.95$.

Prosocial behavior. For the measure of prosocial behavior, we again asked the children to indicate the names of the children in their class who show prosocial behavior (6 items). This measure was derived from Wiegman et al. (1986). Items concerning prosocial behavior are items such as helping another child when he or she does not understand the homework, and sitting next to a new and shy classmate. The prosocial behavior score for a child is the total number of times he or she is mentioned by classmates, divided by the total number of classmates. The internal consistency for this measure was Cronbach's $\alpha=.86$.

Social isolation. The measure for social isolation is taken from the Pupil Evaluation Inventory by Pekarik, Prinz, Liebert, Weintraub, and Neale (1976). Pekarik et al. characterized social isolation as social withdrawal, shyness, and oversensitiveness. The children are to indicate which classmates are socially isolated (Factor 2 of the Pupil Evaluation Inventory; 9 items). We asked the children to indicate who was unhappy or gloomy, and who often does not join in the game. The list also contained items to conceal the purpose of the questions asked (e.g., "Who loves to paint and draw?"). The social isolation score for a child is the total number of times he or she is mentioned by classmates, divided by the total number of classmates. The internal consistency for this measure was Cronbach's $\alpha=.85$.

Loneliness. The loneliness measure was derived from the Loneliness and Social Dissatisfaction Questionnaire by Asher and Wheeler (1985). The children are to indicate whether certain feelings apply to their situation; 10 items concerned feelings of loneliness, and 6 items concern feelings of belonging (sum total of 16 items). The items are measured on a 5-point scale, ranging from 1 (entirely agree) to 5 (entirely disagree). The items from the original instrument for concealing the purpose of the questions were not included. The internal consistency for this measure was Cronbach's $\alpha=.89$.

Popularity. The popularity measure we used consisted of two items and is identical to the measure used by Wiegman et al. (1986). The children are to indicate next to which classmates they would like to sit and which classmates they would like to be friends with. The popularity score is the total number of times a child is mentioned by classmates of the same gender, divided by the total number of classmates of the same gender. The correlation between the two items amounts was .75 for boys and .78 for girls.

Social status. The instrument for defining the social status of a child was taken from Coie, Dodge, and Coppotelli (1982) and Newcomb and Bukowski 
(1983). We asked each child to indicate the three most liked and the three most disliked classmates. On the basis of these two questions, a child can be classified as popular, average, neglected, controversial or rejected. The results were calculated according to the standard score model (Coie et al., 1982) and according to the probability model (Newcomb \& Bukowski, 1983).

School performance. To obtain an indication of a child's school performance, we asked the teachers to rate a child's functioning in school. Teachers gave a total judgment, based on three scholastic skills: (a) general school performance, (b) language skills, and (c) arithmetic skills. By general school performance, we asked for an impression of the total performance in school, except for art and music, and physical education. A rank-order mark was given to a child for each of the three types of school performance: the best pupil received the value 1 , the second best received the value 2 , and so forth. In order to simplify the interpretation of these scores, we subsequently divided the given rank-order marks by the number of children in the group concerned, multiplied these by -1 and added 1 . These transformations resulted in rank-order scores between 0 and 1 , indicating that the higher a child's score, the better a child performed in school.

Intelligence. The Vorm 3 of the Interesse, Schoolvorderingen- en Intelligentietest (ISI; Van Boxtel, Snijders, \& Welten, 1982) was used to establish an indication of a child's intelligence. This intelligence test consists of six subtests: three verbal tests (synonyms, contrasts, and semantic similarity) and three perceptual/motor tests (cut figures, rotated figures, and figure similarity). The split-half reliability for the total intelligence index is .93. The correlations between the total intelligence index and report marks for mathematics, spelling, and silent reading averages $.58, .51$, and .57 , respectively (Van Boxtel et al., 1982).

Results

\section{Leisure Activities}

To establish the reliability of our diary method, we calculated Cronbach's alphas for every activity during 7 days. Values varied between .67 for the amount of time spent playing organized sports and to .81 for watching television, listening to music, and playing nonorganized sports. For the amount of time spent playing videogames, we found a Cronbach's alpha of .77. Thus, these sum scores are a reliable representation of the average time spent on a leisure activity.

Validation of our diary method was obtained by asking the children how often they performed the same leisure activities (5-point scale ranging from 1 [never] to 5 [ a few times every day]). This measure of spending time for each activity correlated between .39 (watching television) and .75 (making music) 


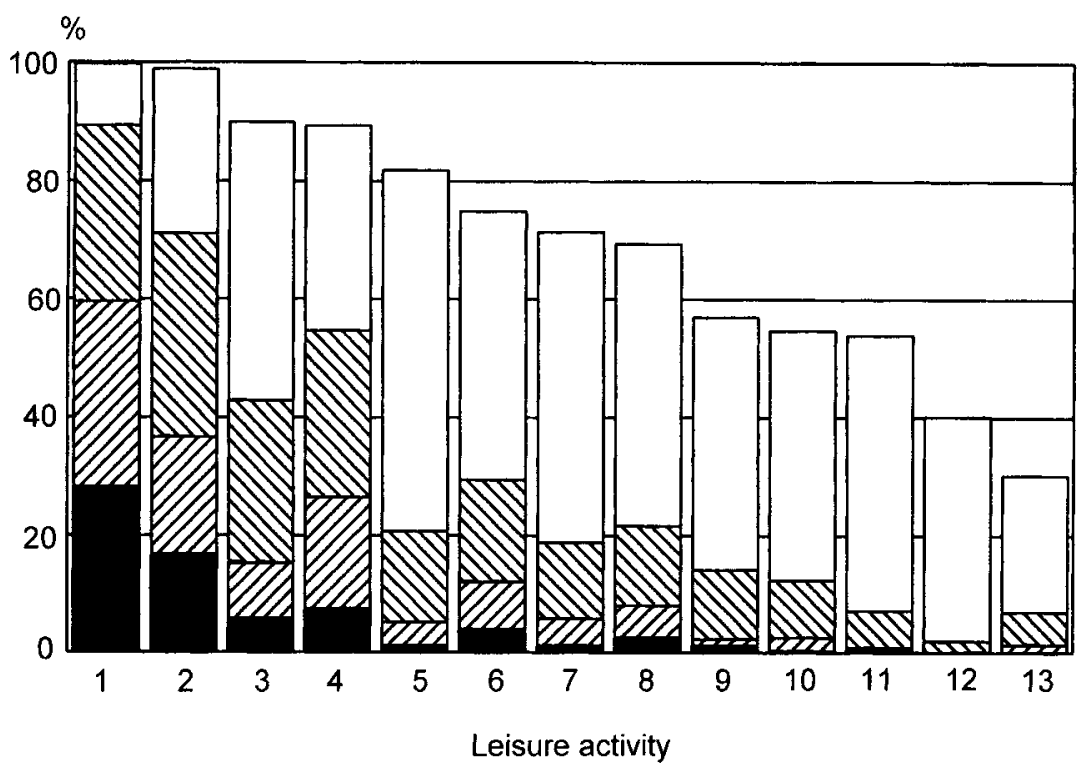

$\square>2$ hours $\square 1$ hour -2 hours $\quad \$ 1 / 2$ hour -1 hour $\square<1 / 2$ hour

Figure 1. Leisure spent by children, averaged by day, in percentages, measured with the diary method. 1 - Watching television; 2 - playing outdoors; 3 - listening to music; 4 - playing indoors; 5 - doing homework; 6 - playing nonorganized sports; 7 - reading books; 8 - playing videogames; 9 - reading comics; 10 - playing organized sports; 11 playing round games; 12 - reading newspapers; 13 - making music.

with the time spent on each activity as measured by the diary method. Time spent playing videogames correlated .61 with the diary method. Because we assumed that the diary method might be a more precise measurement to estimate the time children spent on their day-to-day activities, we decided to use these data in further analyses.

Figure 1 reports on how much time, on average, the children spent on leisure activities each day. Playing videogames ranked eighth, after activities such as watching television, listening to music, doing homework, and reading books, on which more children spent their free time. About $70 \%$ of the children played videogames at least once in the week concerned. Only 16 children (5\%) had played videogames every day of the week. Of the children in our study, $3 \%$ indicated that their time playing videogames averages more than $2 \mathrm{hr}$ per day. About $6 \%$ played between 1 and $2 \mathrm{hr}$ per day, $14 \%$ played between $30 \mathrm{~min}$ and $1 \mathrm{hr}$ per day, and $48 \%$ played less than $30 \mathrm{~min}$ per day on average. 
Table 3

Correlation Between Time Spent Per Day Playing Videogames and Time Spent Per Day on Other Leisure Activities ( $\mathrm{n}=346$ )

\begin{tabular}{lcc}
\hline \multicolumn{1}{c}{ Leisure activity } & \multicolumn{2}{c}{ Playing videogames } \\
\cline { 3 - 4 } \multicolumn{1}{c}{} & $r$ & $p$ \\
\hline Watching television & .30 & $<.001$ \\
Listening to music & .08 & $n s$ \\
Making music &. .04 & $n s$ \\
Reading books & .01 & $n s$ \\
Reading newspapers & .12 & $<.05$ \\
Reading comics & .16 & $<.01$ \\
Playing organized sports & .02 & $n s$ \\
Playing nonorganized sports & .13 & $<.05$ \\
Playing outdoors & .06 & $n s$ \\
Playing round games & .07 & $n s$ \\
Playing indoors & .11 & $<.05$ \\
Doing homework & .06 & $n s$ \\
Working on computer & .23 & $<.001$ \\
\hline
\end{tabular}

Boys played videogames significantly more often than did girls $\left(M_{\text {boys }}=1.93\right.$, $\left.M_{\text {girls }}=1.46\right), F(1,344)=30.08, p<.001$. We found that $35 \%$ of the boys and only $9 \%$ of the girls spent more than 30 min per day playing videogames.

Table 3 represents correlations between time spent playing videogames and time spent on other leisure activities. The more time children spent playing videogames, the significantly more time they spent watching television, reading newspapers and comics, playing nonorganized sports, playing indoors, and working on the computer.

\section{Videogames and Aggressive and Prosocial Behavior}

In the analyses of the variables based on the judgments of classmates (aggressive and prosocial behavior, popularity, social status, and social isolation), we omitted four groups from analyses. The reason for doing this was that these groups contained less than 20 children, which has negative consequences for the reliability of these measurement instruments (Wiegman et al., 1986). 
Table 4

Correlations Between Amount of Time Spent Playing Videogames and Aggression, Social Integration, and School Performance

\begin{tabular}{|c|c|c|c|}
\hline \multirow{2}{*}{$\begin{array}{l}\text { Aspects of } \\
\text { playing } \\
\text { videogames }\end{array}$} & \multicolumn{3}{|c|}{ Playing videogames } \\
\hline & $r$ & $p$ & $n$ \\
\hline \multicolumn{4}{|l|}{ Aggression } \\
\hline Aggressive behavior & .07 & $n s$ & 277 \\
\hline Prosocial behavior & -.12 & $<.05$ & 277 \\
\hline \multicolumn{4}{|l|}{ Social integration } \\
\hline Social isolation & -.01 & $n s$ & 277 \\
\hline Loneliness & -.05 & $n s$ & 342 \\
\hline \multicolumn{4}{|l|}{ Popularity ${ }^{\mathrm{a}}$} \\
\hline Boys & -.14 & $n s$ & 132 \\
\hline Girls & .09 & $n s$ & 142 \\
\hline \multicolumn{4}{|l|}{ School performance } \\
\hline General school performance & .05 & $n s$ & 344 \\
\hline Language skills & .08 & $n s$ & 344 \\
\hline Arithmetic skills & .02 & $n s$ & 344 \\
\hline
\end{tabular}

${ }^{a}$ Boys have been judged by boys; girls have been judged by girls.

Relationships between time spent on videogames and aggression and prosocial behavior are reported in Table 4 . This table also represents relationships between playing videogames and the extent of children's social integration and school performance.

It can be seen from Table 4 that there was no significant relationship between judgments on the amount of aggressive behavior and the amount of time a child spent playing videogames. Children who spent a lot of time on playing videogames were judged by their classmates as significantly less prosocial. However, separate analyses for boys and girls did not demonstrate this significant result.

\section{Videogames and Social Integration}

Table 4 shows no significant relationship between time spent playing videogames and a child's social isolation, loneliness, and popularity. 
A one-way ANOVA for a child's social status with relation to the amount of time spent playing videogames showed no significant differences, standard score model: $\left(M_{\text {popular }}{ }^{4}=1.83, M_{\text {average }}=1.77, M_{\text {neglected }}=1.74, M_{\text {controversial }}=\right.$ $\left.1.43, M_{\text {rejected }}=1.68\right), F(4,272)=0.58, p \leq .68$; probability model: $\left(M_{\text {popular }}=\right.$ $\left.1.81, M_{\text {average }}=1.75, M_{\text {neglected }}=1.71, M_{\text {controversial }}=1.68, M_{\text {rejected }}=1.70\right)$, $F(4,272)=0.10, p \leq .98$.

\section{Videogames and School Performance}

Table 4 showed that no significant relationships arose between amount of time spent playing videogames and the children's school performance. Correlational analyses demonstrated that children who spent more time playing videogames had a significantly higher IQ $(r=.09, p<.05)$. As predicted, we found a significantly positive correlation between a child's IQ and arithmetic skills $(r=.41, p<.001)$, language skills $(r=.41, p<.001)$, and general school performance $(r=.44, p<.001)$.

We computed partial correlations between time spent playing videogames and the various indicators of school performance, controlling for the effect of intelligence. No significant correlations were found between the amount of time spent on videogames and general school performance $(r=-.01)$, arithmetic skills $(r=.02)$, and language skills $(r=-.03)$, respectively.

\section{Discussion}

In this study, we investigated the relationship between playing videogames and leisure activities, aggressive and prosocial behavior, social integration, and school performance of children in the Netherlands. By having children fill out a diary, insight was obtained in the everyday use of videogames by children and related effects. The diary proved to be a reliable and valid instrument to map out children's leisure activities.

Our study revealed that about $70 \%$ of the children had played videogames in a certain week (boys $=75 \%$, girls $=63 \%$ ). This is a relatively low percentage compared to the ones found by Kruse (1992) in earlier research in The Netherlands $(87 \%$ occasionally played videogames on a game computer; $84 \%$ occasionally played videogames on a personal computer), by Joossens (1994) in Flanders (boys $=93 \%$, girls $=63 \%$ ), and Shimai et al. (1990) in Japan (boys = $97 \%$, girls $=92 \%$ ). Lin and Lepper (1987) established in research among American children that $62 \%$ of the boys and $41 \%$ of the girls used the computer for playing videogames.

\footnotetext{
${ }^{4}$ The higher the mean value, the more time spent playing videogames.
} 
Only $3 \%$ of the children in this study indicated that their time playing videogames averaged more than $2 \mathrm{hr}$ per day, $6 \%$ played between 1 and $2 \mathrm{hr}$ per day, $14 \%$ played between $30 \mathrm{~min}$ and $1 \mathrm{hr}$ per day and $48 \%$ played less than $30 \mathrm{~min}$ per day. For that matter, compared with other leisure activities, playing videogames ranked eighth.

With respect to the relationship between the amount of time spent playing videogames and other leisure activities, we found that children who spent more time playing videogames also spent more time watching television, reading newspapers, reading comics, playing nonorganized sports, playing indoors, and working on the computer. The strong relationship established in our study between playing videogames and watching television links up with results of earlier research by Selnow (1984), who posited that this mainly concerns children from so-called "constant television households." What is new is that children who spent more time on videogames also spent more time on other activities such as reading newspapers and comics. On account of the abovementioned results, we could carefully conclude that playing videogames is not at the expense of other leisure activities. Moreover, the children who spent more time on videogames seem to be more active overall.

As Lin and Lepper (1978), Dominick (1984), Fling et al. (1992), and Sakamoto (1994) reported, we found that boys spent more time playing videogames than did girls. The group of heavy players consists mainly of boys, and only a few girls played videogames for more than $2 \mathrm{hr}$ per day on average. By explaining why boys spent more time on videogames, we concur with Eagly's (1987) social role theory. Eagly's research into gender stereotypes shows that there is strong agreement about definitions of masculine and feminine characteristics. Typical masculine positive characteristics are competency, rationality, and assertiveness. Typical feminine positive characteristics are friendliness, sensitivity, and emotional warmth. Negative masculine characteristics are aggression and rudeness; and negative feminine characteristics are passivity and conformism. Women and men identify with their positive and negative gender stereotypes and think it desirable to behave in accordance with these stereotypes. Men and women who behave in a manner deviant from their gender stereotypes are negatively appreciated. For individuals to behave according to their stereotypes can even be rewarding. Videogame themes often revolve around aggression, and many videogames contain aggressive behavior (Bowman \& Rotter, 1983; Wiegman \& Van Schie, 1996). Thus, a great deal of videogames answer to the masculine gender stereotype, and as a result of this these games are less often played by girls.

Fling et al. (1992) found that the more often children played videogames, the more aggressive their behavior wais considered to be. In our study, the results of Fling et al. could not be reproduced. Children who spent more 
time on playing videogames were not judged by their classmates as more aggressive than children who did not play these games. By establishing no relationship between playing videogames and aggressive behavior, we find no support for any of the theoretical approaches we mentioned earlier: neither the stimulation model nor the catharsis model was supported.

On the basis of research by others, Chambers and Ascione (1987) stated that prosocial behavior can be decreased by observing an aggressive or selfish model, by playing competitive games, and by punishment. In their research, Chambers and Ascione concluded that playing aggressive videogames tends to suppress children's prosocial behavior. For the whole group of children in our research, we found an indication for a significant negative relationship between playing videogames and prosocial behavior. When we performed separate analyses for boys and girls, no such relationship emerged. However, because only a few girls $(n=16)$ reported to spending a great deal of time on videogames, we recommend caution in interpreting this result.

The fact that we found no significant relationship between playing videogames and aggressive behavior and no clear relationship between playing videogames and prosocial behavior may be due to our measure which concerned videogame playing in general. In this research, we made no reference to the case that different types of videogames may produce different effects. Relationships between playing videogames and aggressive and prosocial behavior may emerge if, in new research, Griffiths' (1993) nine classes of videogames are used. He recognized that there is a general need for a taxonomy of videogames, as it could be the case that some games have positive effects, while others have very negative effects.

The aspects of a child's social integration we discerned-social isolation, loneliness, popularity, and social status-displayed no connection with the amount of time spent on playing videogames. These results link up with research by Sakamoto (1994), who showed that the child's social status was not related to the amount of time spent playing videogames. These results also agree with the findings of Lin and Lepper (1987), who established that the use of videogames was not related to the amount of social isolation. As yet, these results do not support Selnow (1984), who pointed out that children perceive videogames as an electronic friend.

Lin and Lepper (1987) found that it was mainly boys who spent a lot of time playing arcade videogames who had lower ratings given to them by their teacher on math ability and general academic competence. They found no such relationship between home videogame use and academic performance. In our study, in addition to school performance we also included IQ, verbal intelligence, and perceptual intelligence. Similar to Lin and Lepper, we also found no relationship between videogame use and school performance, not even after 
correction for a child's intelligence. Our expectation that there is a positive relationship between amount of time spent on videogames and a child's IQ was supported. A possible explanation for this relationship is that many videogames appeal to a child's concentration and cognitive skills, important aspects of intelligence.

In conclusion, we suggest that time spent playing videogames appears not to be at the expense of a child's other leisure activities, social integration, and school performance. No positive relationship was found between the amount of time children spent on videogames and aggressive behavior. We found a significant negative relationship between playing videogames and prosocial behavior. However, separate analyses for boys and girls revealed no such relationship.

In order to gain more insight into the effects of playing videogames on a child's social, cognitive, and psychic development, longitudinal research in particular is desired. Because a large percentage of the children reported playing videogames-though at first glance this seems to be not at the expense of other social activities and scholastic obligations-more detailed research is warranted: research that specifically examines the relationship between the content of videogames and children's aggressive and prosocial behavior, social integration, and school performance.

\section{References}

Anderson, C. A., \& Ford, C. M. (1986). Affect of the game player: Short-term effects of highly and mildly aggressive video games. Personality and Social Psychology Bulletin, 12, 390-402.

Asher, S. R., \& Wheeler, V. A. (1985). Children's loneliness: A comparison of rejected and neglected peer status. Journal of Consulting and Clinical Psychology, 53, 500-505.

Bandura, A. (1977). Social Learning Theory. Englewood Cliffs, NJ: Prentice Hall.

Bandura, A. (1986). Social foundations of thought and action: A social cognitive theory. Englewood Cliffs, NJ: Prentice Hall.

Bowman, R. P., \& Rotter, J. C. (1983). Computer games: Friend or foe? Elementary School Guidance and Counseling, 18, 25-34.

Central Bureau of Statistics. (1993). Statistisch jaarboek 1993 [Statistical yearbook]. Den Haag, The Netherlands: SDU.

Central Bureau of Statistics. (1994). Sociaal-economische maandstatistiek, September 1994 [Socioeconomic month statistics]. Den Haag, The Netherlands: SDU.

Chambers, J. H., \& Ascione, F. R. (1987). The effects of prosocial and aggressive videogames on children's donating and helping. Journal of Genetic Psychology, 148, 499-505. 
Coie, J. D., Dodge, K. A., \& Coppotelli, H. (1982). Dimensions and types of social status: A cross-age perspective. Developmental Psychology, 18, 557-570.

Colwell, J., Grady, C., \& Rhaiti, S. (1995). Computer games, self-esteem and gratification of needs in adolescents. Journal of Community and Applied Social Psychology, 5, 195-206.

Cooper, J., \& Mackie, D. (1986). Videogames and aggression in children. Journal of Applied Social Psychology, 16, 726-744.

Dominick, J. R. (1984, Spring). Videogames, television violence, and aggression in teenagers. Journal of Communication, 34, 136-147.

Eagly, A. H. (1987). Sex differences in social behavior: A social-role interpretation. Hillsdale, NJ: Lawrence Erlbaum.

Feshbach, S., \& Singer, R. D. (1971). Television and aggression: An experimental field study. San Francisco, CA: Jossey-Bass.

Fling, S., Smith, L., Rodriguez, T., Thornton, D., Atkins, E., \& Nixon, K. (1992). Videogames, aggression, and self-esteem: A survey. Social Behavior and Personality, 20, 39-46.

Funk, J. B. (1992). Video games: Benign or malignant? Developmental and Behavioral Pediatrics, 13, 53-54.

Gardner, J. E. (1991). Can the Mario Bros. help? Nintendo games as an adjunct in psychotherapy with children. Psychotherapy, 28, 667-670.

Graybill, D., Kirsch, J. R., \& Esselman, E. D. (1985). Effects of playing violent versus nonviolent video games on the aggressive ideation of aggressive and nonaggressive children. Child Study Journal, 15, 199-205.

Griffiths, M. D. (1991). Amusement machine playing in childhood and adolescence: A comparative analysis of video games and fruit machines. Journal of Adolescence, 14, 53-73.

Griffiths, M. D. (1993). Are computer games bad for children? The Psychologist, 6, $401-407$.

Griffiths, M. D., \& Hunt, N. (1993, December). The acquisition, development, and maintenance of computer game playing in adolescence. Paper presented at the BPS London Conference, City University, London, England.

Hearold, S. (1986). A synthesis of 1043 effects of television on social behavior. In G. Comstock (Ed.), Public communication and behavior (Vol. 4, pp. 65133). San Diego, CA: Academic.

Joossens, L. (1994). Zijn videospelen verslavend? Een onderzoek naar het gebruik van videospelen door kinderen in Vlaanderen [Are videogames addictive? A study into the use of videogames by children in Flanders]. Belgium: O.I.V.O./C.R.I.O.C.

Kestenbaum, G. I., \& Weinstein, L. (1985). Personality, psychopathology, and developmental issues in male adolescent video game use. Journal of the American Academy of Child Psychiatry, 24, 329-333. 
Kruse, C. (1992). Mam, ik heb nog zeven levens! Kind en computer in de vrije tijd [Mom, I have another seven lives! Child and computer in leisure time]. Leiden, The Netherlands: Rijks Universiteit Leiden.

Kuttschreuter, M., Wiegman, O., \& Baarda, B. (1986). Television viewing related to aggressive and prosocial behavior: A longitudinal study in the Netherlands compared with that in five other countries. In L. Pulkkinen \& J. Martin Ramirez (Eds.), Aggression in children (pp. 113-147). Sevilla, Spain: Publicaciones de la Universidad de Sevilla.

Lin, S., \& Lepper, M. R. (1987). Correlates of children's usage of videogames and computers. Journal of Applied Social Psychology, 17, 72-93.

Malone, T. W. (1981). Toward a theory of intrinsically motivating instruction. Cognitive Science, 4, 333-369.

Mitchell, E. (1985). The dynamics of family interaction around home video games. Personal Computers and the Family, 8, 121-135.

Newcomb, A. F., \& Bukowski, W. M. (1983). Social impact and social preference as determinants of children's peer group status. Developmental Psychology, 19, 856-867.

Paik, H., \& Comstock, G. (1994). The effects of television violence on anti-social behavior: A meta-analysis. Communication Research, 21, 516-546.

Pekarik, E. G., Prinz, R. J., Liebert, D. E., Weintraub, S., \& Neale, J. M. (1976). The Pupil Evaluation Inventory: A sociometric technique for assessing children's social behavior. Journal of Abnormal Child Psychology, 4, 83-97.

Sakamoto, A. (1994). Video game use and the development of sociocognitive abilities in children: Three surveys of elementary school students. Journal of Applied Social Psychology, 24, 21-42.

Schutte, N. S., Malouff, J. M., Post-Gorden, J. C., \& Rodasta, A. L. (1988). Effects of playing videogames on children's aggressive and other behaviors. Journal of Applied Social Psychology, 18, 454-460.

Selnow, G. W. (1984, Spring). Playing videogames: The electronic friend. Journal of Communication, 34, 148-156.

Shimai, S., Masuda, K., \& Kishimoto, Y. (1990). Influences of TV games on physical and psychological development of Japanese kindergarten children. Perceptual and Motor Skills, 70, 771-776.

Shotton, M. (1989). Computer addiction? A study of computer dependency. London, England: Taylor and Francis.

Silvern, S. B., \& Williamson, P. A. (1987). The effects of video game play on young children's aggression, fantasy, and prosocial behavior. Journal of Applied Developmental Psychology, 8, 453-462.

Soper, W. B., \& Miller, M. J. (1983). Junk time junkies: An emerging addiction among students. School Counselor, 31, 40-43. 
Stowbridge, M. D., \& Kugel, P. (1983, April). Learning to learn by learning to play. Creative Computing, 180-188.

Thissen-Pennings, M. C. E., \& Ten Brink, P. W. M. (1994). KUNST SOCSTAT: Sociometric status, user's manual. Nijmegen, The Netherlands: Katholieke Universiteit Nijmegen, Groep Rekentechnische Dienstverlening, Discipline Psychologie.

van Boxtel, H. W., Snijders, J. T., \& Welten, V. J. (1982). ISI interesse, schoolvorderingen, intelligentie: Verantwoording van het prestatiegedeelte en handleiding voor de gehele testreeks [ISI interest, school performance and intelligence: An account of the performance part and manual for the entire test series]. Groningen, The Netherlands: Wolters-Noordhoff bv.

Wiegman, O. (1975). Aanstekelijkheid van gedrag (Contagion of behavior). Unpublished doctoral dissertation State University of Utrecht, The Netherlands.

Wiegman, O., Kuttschreuter, M., \& Baarda, B. (1986). Television viewing related to aggressive and prosocial behavior. Den Haag, The Netherlands: Stichting voor Onderzoek van het Onderwijs.

Wiegman, O., Kuttschreuter, M., \& Baarda, B. (1992). A longitudinal study of the effects of television viewing on aggressive and prosocial behaviors. British Journal of Social Psychology, 31, 147-164.

Wiegman, O., Seydel, E., \& Baarda, B. (1983). Holland: Research on the causes and prevention of aggression. In A. P. Goldstein \& M. H. Segall (Eds.), $A g$ gression in global perspective (pp. 93-220). New York, NY: Pergamon.

Wiegman, O., \& van Schie, E. G. M. (1996). Video game playing and its relations with aggressive and prosocial behavior. Unpublished manuscript, University of Twente, Department of Psychology, Enschede, The Netherlands.

Winkel, M., Novak, D. M., \& Hopson, H. (1987). Personality factors, subject gender, and the effects of aggressive video games on aggression in adolescents. Journal of Research in Personality, 21, 211-223.

Wood, W., Wong, T. Y., \& Chachere, J. G. (1991). Effects of media violence on viewers' aggression in unconstrained social interaction. Psychological Bulletin, 109, 371-383. 